\title{
SOSYAL HARCAMALAR İLE GELİR DAĞILIMI ARASINDAKİ İLIŞKINIIN İNCELENMESİ: OECD ÜZERINE BİR UYGULAMA
}

\section{Dr. Öğr. Üyesi Hakan KALKAVAN}

İstanbul Medipol Üniversitesi, İşletme ve Yönetim Bilimleri Fakültesi, Ekonomi ve Finans Bölümü, Post Doktora Araştırmacısı, Durham Üniversitesi

hkalkavan@medipol.edu.tr

ORCID: 0000-0003-4482-0505

\section{Öğr. Gör. İrfan ERSİN}

İstanbul Medipol Üniversitesi, Sosyal Bilimler MYO, Dış Ticaret Programı iersin@medipol.edu.tr

ORCID: 0000-0002-7407-3654

Başvuru Tarihi:20.12.2019 Kabul Tarihi: 19.05.2020

DOI: $10.21441 /$ sosyalguvence. 823668

\section{ÖZ}

Sosyal harcamalar, bir toplumda düşük gelir guruplarının belli refah seviyesine erişebilmeleri için yapılan destekleri kapsayan bir ekonomi politikasıdır. Bir ülkenin ekonomik büyüme performansında başarı sağlaması, kalkınması için yeterli bir gösterge değildir. Büyümenin yanında, milli gelirin hanehalkı arasında adil paylaşımı da önemli bir makroekonomik meseledir. Bu sorunun giderilmesinde sosyal harcamalar bir çözüm yolu olarak ortaya konmaktadır. Çalışmamız bu çözüm yolunun işlerliğini test etmek adına sosyal harcamalar ile gelir dağılımı arasındaki ilişkiyi incelemektedir. OECD ülkelerinin kapsam olarak alındığı çalışmamızda 1980-2015 dönemi, Pedroni ve Kao Panel Eşbütünleşme ve Dumitrescu-Hurlin Panel nedensellik yöntemleri ile dikkate alınmıştır. Analiz sonuçlarına göre, OECD ülkelerinde sosyal harcamalar ve gelir dağılımı arasında anlamlı bir ilişki tespit edilmiştir. Dahası sosyal harcamalardan gelir dağılımına nedensellik ilişkisi bulunmuştur. Politik öneri olarak OECD bünyesinde sosyal harcamalar için ortak bir fon oluşturulması ve bu fonun yoksul gruplara ulaştırılması sunulmuştur.

Anahtar Kelimeler: Sosyal Harcamalar, Gelir Dağılımı, Gini Katsayısı, Pedroni Eşbütünleşme, Dumitrescu-Hurlin Nedensellik, OECD 


\title{
INVESTIGATION OF THE RELATIONSHIP BETWEEN SOCIAL EXPENDITURES AND INCOME DISTRIBUTION: AN APPLICATION ON OECD
}

\begin{abstract}
Social spending is an economic policy that encompasses the support of low-income groups in a society to achieve a certain level of prosperity. Success in a country's economic growth performance is not a sufficient indicator for its development. In addition to growth, the fair share of national income among households is an important macroeconomic issue. In order to solve this problem, social expenditures are put forward as a solution. Our study examines the relationship between social expenditures and income distribution in order to test the functionality of this solution. Pedroni and Kao Panel Cointegration, and Dumitrescu-Hurlin Panel have been used for causality methods in the period 1980-2015. According to the results of the analysis, a significant relationship has been found between social expenditures and income distribution in OECD countries. Moreover, causality relationship has been found from social expenditures to income distribution. As a political proposal, a joint fund for social expenditures within the OECD is provided and this fund is delivered to poor groups.
\end{abstract}

Keywords: Social Expenditures, Income Distribution, Gini Coefficient, Pedroni Cointegration, Dumitrescu-Hurlin Causality, OECD 


\section{GíRiş}

Geçtiğimiz 30 yılda gelir eşitsizliği ve refah sorunu global dünyada ülke ekonomileri için oldukça önemli hale gelmiştir. 1990'lardan bu yana, OECD (Ekonomik İşbirliği ve Kalkınma Örgütü) ülkelerinin çoğunda tüm dünyada olduğu gibi gelir eşitsizliği artmıştır. Kamu sosyal harcaması, gelir eşitsizliğini doğrudan düzenlemenin bir yoludur (Ulu, 2018). Bu bağlamda devletlerin sosyal harcamaları, dünyadaki yoksulluk ve eşitsizliği azaltma konusunda mevcut önemli politikalardan biri olmaktadır.

Gelişmişlik göstergelerinden biri olan sosyal adalet, bir toplumda yaşayan bireylerin kaynak ve hizmetlere ulaşmada firsat eşitliğine sahip olup olmadığını gösteren bir kavramdır. Sosyal bilimciler başta olmak üzere siyasi karar vericilerin üzerinde önemle durduğu sorunlar arasında yer alan sosyal adalet, toplumların refah seviyesi hakkında bilgi veren bir değişkendir. Gelir adaleti üzerinde etkili olan ekonomik konulardan biri olan vergi politikası, her devlet için merkezi öneme sahiptir. Vergi geliri olmadan, refah politikaları dahil olmak üzere diğer tüm devlet politikalarının başarısız olması kaçınılmazdır. Refah devleti ve adil gelir dağılımı için en güçlü araç, hakkaniyetli bir vergi sistemi oluşturmaktır (Seelkopf ve Lierse, 2016). Yoksulluk eğilimleri kısmen, geleneksel refah devleti programlarının sosyal yatırım politikalarına dönüştürülmesine bağlanabilmektedir (Van Vliet ve Wang, 2015). Sosyal koruma, ekonomik büyüme ve gelir eşitsizliği arasındaki ilişki modern toplumlarda önemli bir konudur. Ancak, bu faaliyetlerle ilgili herhangi bir fikir birliği yoktur, çünkü yetersiz bütçe nedeniyle veya sistemin verimliliğini azaltabileceği için devletler tarafindan verimsiz bir şekilde gerçekleştirilebilmektedir (Álvarez-García vd., 2015). Yeniden dağıtım; hanehalkı düzeyinde mikro verilere dayanarak kişisel gelir vergileri, çalışanların sosyal güvenlik primleri ve nakit transferleri ile elde edilen, piyasa geliri eşitsizliğindeki nispi azalma olarak tanımlanmaktadır (Causa ve Hermansen, 2018).

Sosyal devlet anlayışı bireyler arasındaki gelir eşitsizliğini azaltmayı amaçlamaktadır. İnsanlar, yetenekleri, sosyo-ekonomik geçmişleri ve firsatları bakımından farklılık göstermekte ve böylece gelir seviyelerinde büyük farklılıklar oluşmaktadır. Bununla birlikte sosyal devlet anlayışında sosyal koruma önemli bir yere sahiptir. Sosyal koruma, yoksulluğu giderici devlet politikalar olarak tanımlanmakta ve işsizlik ödenekleri, çocuk yardım parası, sağlık sigortası, emeklilik ödemeleri gibi sosyal harcama konularını kapsamaktadır. Hükümetler, piyasa gelirlerinin vergiler ve sosyal transferler yoluyla kişilerarasında yeniden dağıtılmasını sağlarlar. Son yıllarda sosyal koruma sistemlerinin gelir eşitsizliği üzerindeki etkisi üzerine ampirik araştırmalarda önemli ilerlemeler kaydedilmiş ve bu araştırmalar literatür kısmında ayrıntılı açıklanmıştır. Bu bağlamda OECD, 
kamu ve özel sosyal harcamalar üzerine kapsamlı çalışmalar yapmıştır (Adema, 2001; Adema ve Ladaique, 2005; Goudswaard ve Caminada, 2014). Modern refah devletleri, yalnızca doğrudan kamu sektörü aracıllı̆ıyla değil, aynı zamanda özel sektör aracılığıyla, örneğin istihdama dayalı hükümleri zorunlu kılarak ve gönüllü işlemler için vergi indirimleri sağlayarak sosyal koruma yararları sağlamaktadır (Konishi ve Miyazato, 2018).

Pek çok OECD devleti vergi politikası yoluyla sosyal politika hedeflerini takip etmektedir. Önlem olarak iki tür vergi politikası kullanılmaktadır. Bunlardan ilki belirli bir gelirin vergilendirilmesinin azaltılması (Anglo-Sakson ülkeleri), ikincisi ise alt sınıfların asgari gerekli kamu desteğini sağlamaktır. Günümüzde Avrupa Birliği'nin sosyal devlet kavramına yaklaşımı ise W. Beck, van der Maesen ve A.Walker tarafından önerilen 'sosyal kalite' kavramına dönüşmüştür. Sosyal kalite tanımı da "vatandaşların refah ve bireysel yeteneklerinin artması için sosyal ve ekonomik hayata katılabildiği ölçüdedir" şeklinde ifade edilmektedir (Adema vd., 2011). Buna göre maksimum sosyal kalite seviyesine ulaşmak için dört gösterge incelenmektedir: Sosyo-ekonomik güvenlik, sosyal kaynaklar veya hanehalkı tipleri, nakit yardımların değiştirilmesi ve özel hizmetlerin teşvik edilmesi (Beck vd, 2001; Kadomtseva ve Palochkina, 2015).

Sosyal harcamaların gelir eşitsizliği üzerindeki etkisini araştıran bu çalışmada OECD ülkeleri kapsam olarak dikkate alınmıştır. Bu çerçevede çalışmanın giriş bölümünde refah devleti, sosyal adalet ve gelir adaletsizliğini azaltıcı vergi politikaları tartışılmıştır. Birinci bölüm olan literatür değerlendirmesinde ise sosyal yatırım politikalarının sonuçlarına odaklanan birçok karşılaştırmalı ampirik analizler, detaylı bir şekilde irdelenmiştir. İkinci bölümde de sırasıyla araştırma konusuna uygun olarak tasarlanan metodoloji ve bulgular üzerinde durulmuştur. Sonuç bölümünde ise araştırma bulgularının değerlendirilmesi yapılmış ve politik öneriler sunulmuştur.

\section{LITERATÜR DEĞERLENDİRMESİ}

Sosyal harcamalar ile gelir adaletsizliği arasındaki ilişkiyi inceleyen pek çok çalışma vardır. Spesifik olarak OECD ülkelerinde, güçlü bir sosyal politika sisteminin ülkedeki gelir adaletsizliğini azalttığını gösteren pek çok ampirik çalışma mevcuttur. Araştırma konusuna uygun olarak kamu tarafindan gerçekleştirilen sosyal harcamalar ve gelir adaletsizliği arasındaki ilişkiyi inceleyen çalışmalar aşağıda ele alınmıştır. Literatür değerlendirmesinde öncelikle OECD ülkelerini kapsam olarak dikkate alan çalışmalara yer verilmiştir.

Sosyal harcamaların refah düzeyine etkisini regresyon yöntemiyle kamu ve özel teşebbüsler açısından inceleyen Goudswaard ve Caminada (2014), 1980- 
2012 döneminde sosyal koruma sisteminin bütün OECD ülkelerinde daha adil gelir dağılımına sebep olduğunu tespit etmişlerdir. Bununla birlikte, kamu sosyal harcamaları ile gelir eşitsizliği arasında negatif bir ilişki olduğunu, ancak özel sektör sosyal harcamaları ile gelir eşitsizliği arasında anlamlı bir ilişki olmadığını bulmuşlardır. Benzer başka bir çalışmada, Sánchez ve Pérez-Corral (2018) Avrupa Birliği'nin 28 üye Devletinde, 2005-2014 döneminde kamu sosyal harcamaları ve gelir eşitsizliği dağılımı arasındaki ilişkiyi Dinamik panel modellerini kullanarak analiz etmişler, kamu sosyal harcaması ile gelir eşitsizliği arasında negatif bir korelasyon, yani kamu sosyal harcamalarının gelir eşitsizliğini azaltıcı bir etki ortaya koyduğu tespit edilmiştir. Diğer taraftan; sosyal harcama, ekonomik büyüme ve gelir eşitsizliği arasındaki ilişkiyi irdeleyen Álvarez-García vd. (2015), 1994-2012 dönemini AB ülkeleri için panel veri yöntemiyle analiz etmişlerdir. Araştırma sonuçlarına göre, kamu sosyal harcamalarının Avrupa ülkelerinin birçoğunda ekonomik büyümeyle ilişkisi olmadığı tespit edilmiştir. Benzer şekilde 1997-2007 dönemi için 15 Avrupa ülkesinde geleneksel refah devleti düzenlemelerinden sosyal yatırım politikalarına kaymanın etkilerini ampirik olarak analiz eden Van Vliet ve Wang (2015), literatürdeki bazı özel durumlarda açıklanan sosyal yatırım politikalarının zararlı etkisinin, daha geniş boyutta Avrupa ülkeleri için genelleştirilemediğini tespit etmişlerdir.

1980'lerden bu yana değişen vergi sistemleri ile birlikte vergi rekabetinin ekonomik eşitsizlik üzerindeki etkilerini inceleyen Seelkopf ve Lierse (2016), hükümetlerin vergi stratejilerinin ve eşitsizlik üzerindeki azaltıcı etkisinin, çoğu zaman kabul edilenden çok daha karmaşık ve heterojen olduğunu belirtmişlerdir. Benzer diğer bir çalışmada Bergh vd. (2017a), OECD Ekonomik Araştırmalarında 1985, 1995 ve 2005 yıllarındaki politika tavsiyesini ölçerek, 24 ülkenin algılanan reform ihtiyacını araştırmışlar ve daha fazla devlet müdahalesine ve daha düşük mülkiyet haklarının korumasına sahip olan ülkelerin daha fazla reform ihtiyacına sahip oldukları sonucuna ulaşmışlardır. Diğer taraftan, küreselleşme ile sosyal adalet arasındaki ilişkiyi 31 OECD ülkesi için araştıran Kauder ve Potrafke (2015), hızlı küreselleşme yaşayan ülkelerin sosyal adaletten daha çok yararlandıkları bulgusuna ulaşmışlardır. Benzer başka bir çalışmada, ekonomik küreselleşme, sosyal koruma harcaması ve ülke içi gelir eşitsizliği arasındaki bağı inceleyen Bergh vd. (2017b; 2019), ekonomik küreselleşmenin yüksek gelir eşitsizliği ile ilişkili olduğunu ve sosyal koruma harcamalarının eşitsizlikle negatif olarak ilişkili olduğu bulgusuna ulaşırken, Araújo ve Simões (2018) küreselleşmeyle ile aile ve işsizlik yardımları arasında anlamlı bir ilişki tespit edememişlerdir.

Kamu harcamalarının verimliliğini Stokastik Sınır Modeli ile tahmin eden Kim, T. ve Kim, H. (2017), çalışmalarında OECD ülkeleri için hangi dışsal faktörlerin etkin olduğunu incelemişlerdir. Araştırma sonucuna göre, işsizlik ve aileye ilişkin 
kamu sosyal harcamaları ve vergi yükü oranının gelir eşitsizliğini önemli ölçüde azaltmakta olduğu diğer taraftan da yolsuzluğun sosyal harcamaları negatif yönde etkilediği tespit edilmiştir. Bununla birlikte, özel sektör sosyal harcamaları entegre ederek OECD ülkelerindeki sosyal koruma sistemlerinin etkilerini SOCX veri tabanı ile tahminleyen Konishi ve Miyazato (2018), sosyal harcamaların özel sektör üzerinden sağlanmasının dağılım etkisini azalttığı bulgusuna ulaşmışlardır. Farklı olarak gelir eşitsizliğinin belirleyici faktörlerini araştıran Tridico (2017), 1990-2013 yılları arası 25 yüksek gelirli OECD ülkesini incelemiştir. Söz konusu çalışmada, son yirmi yıldaki gelir eşitsizliğinin artış sebepleri olarak finans sektörünün kontrolsüz büyümesi, emek esnekliğinin derinleşmesi, sendikaların zayıflaması ve refah devleti uygulamalarının sonlandırılması bulgularına ulaşılmıştır. Benzer konuda diğer bir çalışmada Bayar ve Sasmaz (2018), 2005-2014 dönemi için seçilen Orta ve Doğu Avrupa Birliği ülkelerinde sosyal harcamalar ve yoksulluk arasındaki nedensellik ilişkisini incelemişlerdir. Analiz sonuçlarına göre, sosyal harcamalar ve yoksulluk arasında nedensel bir ilişki tespit edilememiştir. Ulu (2018)'nun çalışmasında kamu sosyal harcamalarının gelir eşitsizliği üzerindeki etkisi 21 OECD ülkesi için incelenmiştir. Söz konusu çalışma sonucunda kamu sosyal harcamalarının artış göstermesi durumunda gelir eşitsizliğinin azaldığ 1 ve gelir eşitsizliğini düzenlemede eğitim harcamalarının daha etkili olduğu tespit edilmiştir. Diğer taraftan Lin vd.'nin (2015) 1988-2005 dönemleri arası 29 OECD ülkesini savunma ve sosyal refah harcamaları açısından inceledikleri araştırmada, askeri harcama ile sosyal refah harcamaları (eğitim ve sağlık) arasında olumlu bir denge olduğu bulunmuştur.

Yilmiz vd.'nin (2016) gelir eşitsizliği ölçütlerini inceledikleri çalışmada, Gini katsayısını etkileyen faktörler arasında ortalama gelir vergisi oranı ve işgücüne katılım oranı arasında doğrusal bir ilişki bulmuşlardır. Bu bağlamda vergilendirme ve işgücüne katılımdaki kamu politikalarının eşitsizlikle başa çıkmak için değiştirilmesi gerektiği gerçeğini vurgulamışlardır. Benzer bir çalışmada Gini endeksi ile Kuzey Makedonya Devleti'nin sosyal transfer harcamalarının sosyoekonomik eşitsizlik üzerindeki etkisini inceleyen Kozuharov ve Petkovski (2018), sosyal transfer harcamalarının eşitsizlik üzerinde etkili olduğunu belirlemişlerdir. Bir diğer çalışmada d'Agostino vd. (2016) devletin sosyal harcamalardaki \%1'lik bir artışın Gini gelir endeksini yarı yarıya düşürdüğünü tespit etmişlerdir.

Causa ve Hermansen'in (2018) çalışmasında ise, OECD ülkelerinin son 20 yıllık verisi ele alınmış ve çalışma çağındaki nüfusun gelir dağılımı değerlendirilmiştir. Söz konusu çalışma sonucunda OECD'de (1990'ların ortasına kadar verilerin mevcut olduğu ülkelerin çoğunda) yeniden dağıtımda yaygın bir düşüş olduğu gösterilmiştir. Benzer bir konuyu ele alan Kranzinger (2019), Avrupa gelir eşitsizliğinin yapısını, 2014 yılında yapılan Avrupa Gelir ve Yaşam 
Koşulları Anketi'nden (AB-28) elde edilen verilerle analiz etmiştir. Buna göre, gelir eşitsizliğinin 59 yaşından büyük haneler için en yüksek, çocuklu haneler için ise en düşük olduğu tespit edilmiştir. Dahası, yüksek gelirli ülkeler daha düşük eşitsizliğe ve daha yüksek sosyal harcamalara sahiptir. Diğer taraftan 1995-2010 yılları arasında seçilen 26 sanayileşmiş ülke için OECD veri setini kullanarak gelir eşitsizliği göstergesini inceleyen Kim (2019), harcanabilir gelir eşitsizliğinin bebek ölümleri dışındaki sağlık göstergelerinin istatistiksel olarak anlamlı bir ilişkiye sahip olmadığını tespit etmiş̧ir. Son olarak sosyal harcamaların ekonomik büyüme üzerindeki etkisini inceleyen Ersin ve Baş'ın (2019) çalışmalarında Güney Avrupa Ülkeleri örneklem olarak alınmış ve 1980-2016 dönemi panel nedensellik ile analiz edilmiştir. Söz konusu çalışma sonucunda ekonomik büyümenin sosyal harcamaların bir nedeni olduğu, yani ekonomik küçülme dönemlerinde sosyal harcamaların artış gösterdiği tespit edilmiştir.

Literatürdeki çalışmalar dikkate alındığında sosyal harcamaların gelir dağılımı üzerindeki etkisini inceleyen çalışmaların yeteri düzeyde olmadıkları görülmektedir. Ayrıca OECD ülkeleri için sosyal harcamaların gelir dağılımı üzerindeki etkisini inceleyen çalışmaların da yöntemsel ve dönemsel olarak farklılıklar sergilediği görülmektedir. Bundan dolayı bu çalışmanın literatüre, yöntemsel olarak panel zaman serilerini kullanması ve sosyal harcamaların gelir dağılımı arasındaki ilişkiyi doğrudan incelemesi bakımından yenilik katacağı düşünülmektedir.

\section{METODOLOJI}

\subsection{Veri Seti ve Yöntem}

$\mathrm{Bu}$ çalışmada, sosyal harcamalar ve gelir dağılımı arasındaki ilişkinin incelenmesinde OECD ülkeleri dikkate alınmıştır. OECD ülkelerinde 1980-2015 arasında verisine ulaşabildiğimiz 15 ülke $^{1}$ analize dahil edilmiştir. Çalışmamızda kullanılan sosyal harcamalar değişkeni OECD verilerinden elde edilerek GSYİH pay1 olarak ele alınmış, gelir dağılımını temsil eden gini katsayısı ise Texas Üniversitesi eşitsizlik projesi kapsamında hesaplanan verilerden elde edilmiştir. Analizde dönem olarak 1980-2015 döneminin ele alınmasının sebebi 1980 yılı için küresel boyutta serbest piyasa ekonomik sisteminin benimsenmesi, 2015 y1lı için ise gelir dağılımı verilerinin söz konusu kaynağa göre bu yıldan sonra hesaplanmamasıdır. Bundan dolayı 1980-2015 dönemi çalışmada analize tabi tutulmuştur. Çalışmamızda kullanılan değişken ad, tanım ve kaynakları Tablo 1'de verilmiştir.

1 Avusturya, Belcika, Danimarka, Estonya, Finlandiya, Fransa, Yunanistan, Norvec, Polonya, İspanya, İsvec, Portekiz, İzlanda,Slovenya, Slovakya, Litvanya, Lüxemburg, İrlanda, Çek Cumhuriyeti, İngiltere 
Tablo 1: Değişken İsimleri²3

\begin{tabular}{l|l|l}
\hline Değişken Adı & Tanım & Kaynak \\
\hline Gini Katsayı (Gelir Dağılımı) & $\begin{array}{l}\text { Gelir dağılımını temsil eden Gini } \\
\text { katsayısı, 0-1 arasında değerlerden } \\
\text { oluşmaktadır. }\end{array}$ & Texas Üniversitesi \\
\hline Social (Sosyal Harcamalar) & $\begin{array}{l}\text { Sosyal harcamalar, GSYİH içindeki } \\
\text { paylardan oluşmaktadır. }\end{array}$ & OECD $^{3}$ \\
\hline
\end{tabular}

Sosyal harcamalar ve gelir dağılımı ilişkisinin analiz edilmesi için ilk olarak değişkenler birim kök testine tabi tutulmuştur. Birim kök testinin yapıldığ 1 çalışmamızda yöntem olarak Pedroni ve Kao eşbütünleşme testleri dikkate alınmış ve ardından Dumitrescu-Hurlin Panel nedensellik testi uygulanmıştır. Panel veri çalışmaları karmaşık davranış modellerini ele alması bakımından zaman serisi ve yatay kesit veri modellerine göre tercih edilmektedir (Tarı, 2010).

Çalışmamızda hem eşbütünleşme hem de nedensellik testlerinin uygulanmasına yönelik boş hipotezler aşağıda belirtilmiştir: yoktur.

$\mathrm{H}_{0}$ : OECD ülkelerinde sosyal harcamalar ile gelir dağılımı arasında ilişki

$\mathrm{H}_{0}$ : OECD ülkelerinde sosyal harcamalar, gelir dağılımının Granger nedeni değildir.

\subsection{Birim Kök Testi}

Zaman serilerinde verilerin durağanlaşmasında kullanılan birim kök testi, panel zaman serisi testlerinde çokça kullanılan yöntemlerdendir. Zaman serilerinin geleceği öngörmede önemli bir yere sahip olması, serilerin zaman içinde mevsimsel etkiler, trend ve düzensiz dalgalanmalar oluşturabilmesi açısından durağanlık önem arz etmektedir. Durağanlaşma, serilerin belli bir değere yaklaşması olarak ifade edilmektedir (Ayvaz, 2006).

Zaman serisi analizlerinde değişkenler durağanlığa sahip olmadıklarında formülü kullanılarak değişkenler durağan hale getirilir. Bu formül ile değişkenler durağan hale getirilinceye kadar farkları alınır. Zaman serisi durağan hale geldiğinde serinin düzeyde bütünleşik olduğu anlaşılır. Bunun yanında söz konusu serinin durağanlığı olarak gösterilir. Panel veri çalışmalarında birim kök testleri için birçok yöntem dikkate alınmaktadır. Literatürde sıklıkla Maddala ve Wu (1999),

2 Texax Üniversitesi Eşitsizlik Projesi kapsamında hesaplanan veriler dikkate alınmıştır. https://utip. lbj.utexas.edu/data.html Erişim Tarihi: 25.11.2019

3 https://stats.oecd.org/Index.aspx?DataSetCode=SOCX_AGG Erişim Tarihi: 25.11.2019 
Choi (2001), Levin vd. (2002) ve Im vd. (2003) çalışmaları referans alınmaktadır. Çalışmamızda da literatürde sıklıkla kabul gören bu testler ele alınmış ve bu testlerin uygulanmasında 4 kaynă̆ın üçünde serilerin durağan olarak kabul görmesi üzerine seriler durağan kabul edilmiştir.

Söz konusu birim kök testlerinin hipotez kurumları ve test istatistik hesaplamaları Dickey-Fuller (1979) ve Genişletilmiş Dickey Fuller (ADF) birim kök testleri üzerinden yapılmaktadır.

$$
\Delta Y_{t}=\beta_{1}+\beta_{2 t}+\delta Y_{t-1}+u_{t}
$$

Denklem 1'de DF testinde en küçük kareler (EKK) yöntemi tahminine dayanan bir model kurulmuştur. $\mathrm{Bu}$ modelde $\mathrm{Y}=0$ hipotezi için birim kök testi uygulanmakta ve hesaplanan $\mathrm{t}$ istatistiği dikkate alınarak karar verilmektedir. $\mathrm{H}_{0}$ : $\mathrm{Y}=0$ olarak kurulan hipotezin reddedilmesi durumunda serinin birim kök içermediği sonucuna ulaşılmaktadır. Genişletilmiş Dickey-Fuller testi ise Denklem 1'deki modele ek olarak hata teriminin ardışı bağımlılık veya değişen varyans sorunu çıkarmaması için bağımlı değişkenin birden fazla gecikme değerini modele dahil etmesiyle yapılmaktadır.

Panel birim kök testlerinde Levin vd. (LLC) (2002) testinde tüm birimler için otoregresif () katsayısı homojen olarak kabul edilmektedir. Im vd. (IPS) (2003) ise katsayı homojen olarak kabul edilmezken, bu teste veriler birleştirilmeden her bir değişken için ayrı birim kök testi uygulanmakta ve ortaya çıkan istatistiklerin ortalamaları alınarak birim kök testi gerçekleşmektedir. Maddala ve Wu (1999) ve Choi (2001) birim kök testlerinde ise Fisher tipi testler önerilmekte ve parametrik olmayan her bir yatay kesit için birim kök test istatistikleri birleştirilmektedir.

\subsection{Pedroni ve Kao Eşbütünleşme Testi}

Zaman serilerinde değişkenlerin birim kök testleri alındıktan sonra eşbütünleşme testi gerçekleştirilebilir. Eşbütünleşme testi, iki değişken arasında ilişkinin varlığını ölçen test olarak ifade edilmektedir. İki ve daha fazla serinin durağanlaştırılarak ilişki ölçümünün yapılabileceğini test eden Engle ve Granger (1987), eşbütünleşme analizinde literatüre önemli bir katkı sağlamıştır. Panel eşbütünleşme testlerinde değişkenler arasında ilişkinin olup olmadığını ölçen testler arasında yaygın olarak Pedroni(1999) ve Kao(1999) eşbütünleşme testleri kullanılmaktadır. Söz konusu testlerde Pedroni (1995 önce iki değişken arasında eşbütünleşme testinin olabileceğini kanıtlarken, sonrasında iki ve daha fazla değişken arasında eşbütünleşme olabileceğini test etmiştir (Pedroni,1999). Kao 
(1999) testi ise "eşbütünleşme yoktur" hipotezinden hareketle DF ve ADF birim kök testlerini önermiştir. Pedroni eşbütünleşmesine ait model aşağıdaki denklemde gösterilmektedir.

$$
y_{i t}=\alpha_{i}+\delta_{i} t+\beta_{1 i} X_{2 i t}+\beta_{2 i} X_{2 i t}+\cdots+\beta_{M i} X_{M i t}+e_{i t}
$$

Pedroni panel eşbütünleşme analizi yapılırken panel v-istatistiği, panel rho-istatistiği, panel Philips-Peron (PP) -istatistiği, panel ADF-istatistiği, grup rho-istatistiği, grup PP-istatistiği ve grup ADF-istatistiği olmak üzere 7 farklı test dikkate alınmaktadır. Bu 7 testin en az 4'ünde olasılık değer 0.05 'ten küçük olduğunda değişkenler arasında eşbütünleşik ilişki olduğu kabul edilir. Yani söz konusu değişkenlerin uzun vadede eşbütünleşik ilişkiye sahip olduğu dikkate alınır (Pedroni, 2001). Kao (1999) yönteminde ise ADF değerinin olasılık değerine bakılır ve bu değer 0.05 'ten küçükse değişkenler arasında eşbütünleşmenin olduğu kabul görür.

\subsection{Dumitrescu-Hurlin Panel Nedensellik Testi}

Granger nedensellik testini temel olarak kabul eden Dumitrescu-Hurlin Panel nedensellik testi, iki değişken arasındaki nedensel ilişkiyi tespit etmeye yönelik bir yöntemdir. Bu testin kullanılmasında en önemli gerekçe panel çalışmalar üzerine uygulanabilmesidir. Söz konusu panel nedensellik testinin model kurulumu aşağıdaki denklemde verilmiştir.

$$
Y_{i, t}=a_{i}+\sum_{k=1}^{K} Z_{i}^{k} Y_{i, t-k}+\sum_{k=1}^{K} B_{i}^{k} X_{i, t-k}+\varepsilon_{i, t}
$$

Denklem 3'te yer alan modele göre Y ile X arasında nedensellik ölçümü yapılmaktadır. Söz konusu denkleme göre ulaşılmak istenen durum X'in Y'nin nedeni olup olmadığıdır. Modelde $X$ değişkenin katsayısı $\mathrm{B}$, bağımlı değişken olan Y'nin gecikmeli değerinin katsayısı da Z olarak gözükmektedir. Modelde K verisi ise optimal gecikme aralığı ile bilgi verirken, simgesi de hata terimini ifade etmektedir.

\section{BULGULAR}

\subsection{Birim Kök Testi}

Eşbütünleşme ve nedensellik analizinden önce değişkenler birim kök testine tabi tutulur. Panel nedensellik testlerinde 4 yöntem sıkça kullanıldığ için çalışmamızda da birim kök testinde Maddala ve Wu (1999), Choi (2001), Levin vd. (2002) ve Im vd. (2003)'nin yöntemleri dikkate alınmış ve en az 3 yöntemde 
değişkenin olasılık değeri 0.05 'ten küçük olması durumunda değişken durağan kabul edilmiştir. Tablo 2'de gini ve sosyal harcama değişkenlerinin birim kök test sonuçları verilmiştir.

Tablo 2: Birim Kök Test Sonuçları

\begin{tabular}{|c|c|c|c|c|}
\hline & \multicolumn{4}{|c|}{ Gini } \\
\hline & \multicolumn{2}{|c|}{ Sabitli } & \multicolumn{2}{|c|}{ Sabitli } \\
\hline & t- istatistiği I(0) & Olasılık I(0) & t- istatistiği I(1) & Olasılık I(1) \\
\hline Levin, Lin \& Chu & -2.31475 & 0.0103 & -12.8168 & 0.0000 \\
\hline $\begin{array}{l}\text { Im, Pesaran and Shin } \\
\text { W-stat }\end{array}$ & -0.34070 & 0.3667 & -14.5388 & 0.0000 \\
\hline $\begin{array}{l}\text { ADF - Fisher Chi- } \\
\text { square }\end{array}$ & 34.3455 & 0.2672 & 241.637 & 0.0000 \\
\hline \multirow[t]{4}{*}{$\begin{array}{l}\text { PP - Fisher Chi-squ- } \\
\text { are }\end{array}$} & 37.3832 & 0.1662 & 345.589 & 0.0000 \\
\hline & \multicolumn{4}{|c|}{ Social } \\
\hline & \multicolumn{2}{|c|}{ Sabitli } & \multicolumn{2}{|c|}{ Sabitli } \\
\hline & t- istatistiği I(0) & Olasılık I(0) & t- istatistiği I(1) & Olasılık I(1) \\
\hline Levin, Lin \& Chu & -0.09818 & 0.4609 & -11.2253 & 0.0000 \\
\hline $\begin{array}{l}\text { Im, Pesaran and Shin } \\
\text { W-stat }\end{array}$ & -0.34070 & 0.3667 & -11.4283 & 0.0000 \\
\hline $\begin{array}{l}\text { ADF - Fisher Chi- } \\
\text { square }\end{array}$ & 34.3455 & 0.2672 & 183.444 & 0.0000 \\
\hline $\begin{array}{l}\text { PP - Fisher Chi-squ- } \\
\text { are }\end{array}$ & 37.3832 & 0.1662 & 253.179 & 0.0000 \\
\hline
\end{tabular}

Tablo 2'de gini ve sosyal harcama değişkenlerinin düzeyde durağanlıklarına bakılırken trend dikkate alınmamış, düzeyde ve birinci farkta sabitli değerler üzerinden testler yapılmıştır. Bunun nedeni test yapılırken gini ve sosyal harcama verilerinin trend içermediğinin gözlemlenmesidir. Gini değişkenini durağanlık testine tabi tuttuğumuzda, Levin vd. (2002)'ne göre gini değişkeni düzeyde durağan kabul edilmekte, diğerlerinde ise durağan kabul edilmemektedir. Gini değişkeninin birinci farkı alındığında durağanlık söz konusu olmaktadır. Sosyal harcamalar değişkenine bakıldığında tüm yöntemlerde değişken düzeyde durağan kabul edilmemekte, birinci farklarında ise değişken durağan hale gelmektedir.

\subsection{Panel ve Kao Eşbütünleşme Testi}

Zaman serilerinde değişkenlerin durağanlık testleri yapıldıktan sonra eşbütünleşme analizi gerçekleştirilebilir. Çalışmamızda eşbütünleşme modelinde gelir dağılımı (gini) bağımlı değişken, sosyal harcamalar ise bağımsız değişken olarak 
dikkate alınmıştır. Sosyal harcamalar ve gelir dağılımı arasındaki ilişkinin varlığını test etmeye yönelik Pedroni ve Kao eşbütünleşme sonuçları Tablo 3 'te verilmiştir. Tablo 3 'te verilen Pedroni eşbütünleşme test sonuçlarında 7 testin 6'sında olasılık değeri 0.05 'ten küçük çıkmış ve boş hipotez reddedilmiştir. Kao eşbütünleşme test sonucunda ise ADF olasılık değeri 0.05 'ten küçük çıkmış ve burada da boş hipotez reddedilmiştir. İki eşbütünleşme sonucunda da sosyal harcamalar ve gelir dağılımı arasında uzun dönemde ilişki tespit edilmiştir. Ayrıca sosyal harcamalar ve gelir dağılımı arasında regresyon analizi sonucunda pozitif ilişki olduğu gözlemlenmiştir. Yani regresyonda sosyal harcamalar katsayısının pozitif olduğu görülmüştür.

Tablo 3: Pedroni ve Kao Eşbütünleşme Test Sonuçları

\begin{tabular}{|c|c|c|c|c|c|}
\hline Boş Hipotez & Test Yöntemi & t-statistic & Prob. & $\begin{array}{l}\text { Weighted } \\
\text { Statistic }\end{array}$ & Prob. \\
\hline \multirow{8}{*}{$\begin{array}{l}\text { Gelir dağılı- } \\
\text { mı ve sosyal } \\
\text { harcamalar } \\
\text { arasında iliş- } \\
\text { ki yoktur. }\end{array}$} & Panel v-Statistic & -0.664714 & 0.7469 & -1.651466 & 0.9507 \\
\hline & Panel rho-Statistic & -20.58797 & 0.0000 & -21.32677 & 0.0000 \\
\hline & Panel PP-Statistic & -28.57979 & 0.0000 & -23.56480 & 0.0000 \\
\hline & Panel ADF-Statistic & -14.59681 & 0.0000 & -12.98228 & 0.0000 \\
\hline & Grup rho-Statistic & -17.18127 & 0.0000 & & \\
\hline & Grup PP-Statistic & -35.56897 & 0.0000 & & \\
\hline & Grup ADF-Statistic & -14.99187 & 0.0000 & & \\
\hline & Kao-ADF & -3.414341 & 0.0003 & & \\
\hline
\end{tabular}

\subsection{Dumitrescu-Hurlin Nedensellik Test Sonuçları}

Granger nedensellik testini temel alan Dumitrescu-Hurlin nedensellik testi, panel verilerde kullanılmakta ve iki değişken arasındaki nedensellik ilişkisini ortaya çıkarmaktadır (Dumitrescu ve Hurlin, 2012). Çalışmamızda uygulanan bu yöntemin sonuçları Tablo 4'de verilmiştir. Söz konusu sonuçlara göre sosyal harcamalardan gelir dağılımına yönelik nedensellikte olasılık değerleri 3 lag değerinde de 0.05 'in altında gerçekleşmiştir. Bu durumda sosyal harcamalar gelir dağılımının Granger nedeni olarak tespit edilmiştir. Gelir dağılımından sosyal harcamalara yönelik nedensellik testinde ise olasılık değerleri 3 lag değerinde de 0.05 'in üstünde çıkmış ve nedensellik ilişkisi söz konusu yönteme göre tespit edilememiştir. 
Tablo 4: Dumitrescu-Hurlin Nedensellik Test Sonuçları

\begin{tabular}{|c|c|c|c|}
\hline Nedensel İlişkinin Yönü & $\begin{array}{l}\text { Lag (Gecikme } \\
\text { Değeri) }\end{array}$ & $\begin{array}{l}\text { Olasılık } \\
\text { Değeri }\end{array}$ & Sonuç \\
\hline \multirow{3}{*}{ Sosyal Harcamalar $\rightarrow$ Gelir Dağılımı } & 1 & 0.0004 & \multirow{3}{*}{$\begin{array}{l}\text { Sosyal harcamalar, ge- } \\
\text { lir dağ1lımının Gran- } \\
\text { ger nedenidir. }\end{array}$} \\
\hline & 2 & 0.0000 & \\
\hline & 3 & 0.0000 & \\
\hline \multirow{3}{*}{ Gelir Dağılımı $\rightarrow$ Sosyal Harcamalar } & 1 & 0.7591 & \multirow{3}{*}{$\begin{array}{l}\text { Gelir dağılımı, sosyal } \\
\text { harcamaların Granger } \\
\text { nedeni değildir. }\end{array}$} \\
\hline & 2 & 0.6703 & \\
\hline & 3 & 0.8955 & \\
\hline
\end{tabular}

\section{SONUÇ}

Sosyal harcamaların yapılmasındaki ana nedenlerden biri de toplumda bireyler arasındaki gelir farklılığını en aza indirmektir. Gelir farklılı̆̆ının oluşmasında da mevcut kapitalist ekonominin zaman zaman getirmiş olduğu krizler önemli bir rol oynamaktadır. Bundan dolayı ülke ekonomi yönetimlerinin öncelikli makroekonomik hedefleri arasında gelir eşitsizliği konusu yer almaktadır. Zira, bir ülkenin ekonomik büyümeyi sağlaması tek başına yeterli bir gösterge değildir. Bireyler arasındaki refah dağılımının adaletli dağıtılması büyümenin de ötesinde kalkınma ile ilgili bir durumdur. Gelir eşitsizliği, ekonomik gelişmişliğin bir göstergesi olarak dikkate alınmaktadır.

Çalışmamızda OECD ülkelerinde sosyal harcamalar ile gelir dağılımı ilişkisi incelenmiş ve 1980-2015 dönemi ele alınmıştır. Pedroni eşbütünleşme ve Dumitrescu-Hurlin Nedensellik testlerinin uygulandığı çalışmamızda sosyal harcamalar ile gelir dağılımı arasında ilişki tespit edilmiş ve bunun yanında sosyal harcamaların gelir dağılımının Granger nedeni olduğu bulunmuştur. Bu sonuçların literatürde Goudswaard ve Caminada (2014), Sánchez ve Pérez-Corral (2018), Kauder ve Potrafke (2015), d'Agostino vd. (2016) ve Ulu (2018)'nun çalışmalarında çıkan sonuçlarla benzerlik arz ettiğini söylemek mümkündür. Bu sonuçlardan yola çıarak sosyal harcamaların çeşitlendirilmesinin ve büyümeye katkı sağlayacak şekilde yapılmasının gelir eşitsizliğini azaltabileceği düşünülmektedir. Ayrıca OECD bünyesinde sosyal harcamalar için ortak bir fon oluşturulması ve bu fonun yoksul gruplara ulaştırılması öneri olarak sunulmaktadır. Fona katkı sağlayacak ülkelerin katkı miktarları, büyüme ve kalkınmışlık göstergeleri ile oranlanmalı, fon dağıtımında ise ülkelerin, yoksulluk ve gelir dağılımları dikkate alınmalıdır. Bununla birlikte sosyal yardım fonlarının kullanım alanları iyi planlanmalıdır. Zira herhangi bir sağlık problemi veya yaşlılık problemi olmayıp sosyal yardımlarla yaşayan asalak bir sınıfın da oluşmamasına dikkat edilmelidir. Zorunlu ihtiyaçların karşılanması öncül olmakla beraber devlet için sosyal harcama yapmaktaki esas 
amaç ve stratejisi, yoksul sınıfı kendi ayakları üzerinde duracak şekilde üreten ve verimlilik sağlayacak koşullara ulaştırmak olmalıdır. Bu politikanın gerçekleşmesi sonucunda OECD kapsamında gelir eşitsizliğinin azalacağı öngörülmektedir.

Sosyal harcamaların gelir dağılımı ile ilişkisi OECD için genel olarak tespit edilirken, ülkelerin gelişmişlik gruplarına göre sosyal harcamalar ve gelir dağılımı ilişkisi, incelenmesi gereken konular arasında gözükmekte ve araştırmacılara yeni araştırma alanları olarak önerilmektedir. Bunun yanında sosyal harcamaların alt bileşenleri ve gelir dağılımı arasındaki ilişkinin incelenmesi de yeni araştırma konusu olarak önerilmektedir. 


\section{KAYNAKÇA}

Adema, W. (2001). Net social expenditure. Oecd Social, Employment And Migration Workıng Papers No. 29.

Adema, W., \& Ladaique, M. (2005). Net social expenditure, 2005 edition: More comprehensive measures of social support (No. 29). OECD Publishing.

Adema, W., Fron, P, Ladaique, M (2011) Is the European Welfare State Really More Expensive? Indicators on Social Spending, 1980-2012; and a Manual to the OECD Social Expenditure Database (SOCX). OECD Social, Employment and Migration Working Paper 124. Paris: Organisation for Economic Co-operation and Development.

Álvarez-García, S., Saez,M.P., \& Castaneda,D.(2015). Is social protectionexpenditure or an investment? A cross-country comparison in the European Union. Journal of Knowledge Management, Economics and Information Technology, 5(6), 1-11.

Araújo, I., \& Simões, M. (2018). Globalisation and the Composition of the Welfare State: Evidence From OECD Countries. In B. Sergi, F. Fidanoski, M. Ziolo, \& V. Naumovski (Eds.), Regaining Global Stability After the Financial Crisis (pp. 257285). Hershey, PA: IGI Global. https://doi.org/10.4018/978-1-5225-4026-7.ch013

Ayvaz, Ö. (2006). Mevsimsel birim kök testi. Atatürk Üniversitesi İktisadi ve İdari Bilimler Dergisi, 20(1), 71-87.

Bayar, Y., \& Sasmaz, M. U. (2018). Social Expenditures and Poverty in Central and Eastern European Union Countries: A Causality Analysis BT - The Impact of Globalization on International Finance and Accounting (D. Procházka, ed.). Cham: Springer International Publishing.

Beck, W., Van Der Maesen, L., Thomese, F., Walker, A., eds (2001). Social Quality: A Vision for Europe. London: Kluwer Law International.

Bergh, A., Dackehag, M., \& Rode, M. (2017a). Are OECD policy recommendations for public sector reform biased against welfare states? Evidence from a new database. European Journal of Political Economy, 48, 3-15. https://doi.org/https:// doi.org/10.1016/j.ejpoleco.2016.09.001

Bergh, A., Mirkina, I., \& Nilsson, T. (2019). Can social spending cushion the inequality effect of globalization? Economics \& Politics. https://doi.org/10.1111/ ecpo. 12143 
Bergh, A., A. Kolev and C. Tassot (2017b). Economic globalisation, inequality and the role of social protection. OECD Development Centre Working Papers, No. 341, OECD Publishing, Paris. https://doi.org/10.1787/c3255d32-en

Caminada, K., \& Goudswaard, K. (2005). Are Public and Private Social Expenditures Complementary? International Advances in Economic Research, 11(2), 175-189. https://doi.org/10.1007/s11294-005-3014-9

Causa, O., \& Hermansen, M. N. (2018). Income redistribution through taxes and transfers across OECD countries. Retrieved from Luxembourg Income Study (LIS) website: http://hdl.handle.net/10419/203015

Choi, I. (2001). Unit root tests for panel data. Journal of International Money and Finance, Elsevier, vol. 20(2), pages 249-272, April.

d'Agostino, G., Pieroni, L., \& Procidano, I. (2016). Revisiting the relationship between welfare spending and income inequality in OECD countries. Tech. Rep. 72020. University Library of Munich, Germany.

Dickey, D. A., \& Fuller, W. A. (1979). Distribution of the estimators for autoregressive time series with a unit root. Journal of the American statistical association, 74(366a), 427-431.

Dumitrescu, E. I. \&Hurlin, C. (2012). Testing for Granger non-causality in heterogeneous panels. Economic Modelling, 294, 1450-1460.

Engle, R. F. \& Granger, C. W. (1987). Co-integration and error correction: representation, estimation, and testing. Econometrica: journal of the Econometric Society, 251-276.

Ersin, İ., \& Baş, H. (2019). Güney Avrupa Refah Ülkelerinde Sosyal Harcamalar Ve Ekonomik Büyüme Arasındaki İlişkinin İncelenmesi. SGD-Sosyal Güvenlik Dergisi, 9(1), 193-213.

Goudswaard, K. \& Caminada, K. (2014). Private social expenditure and the redistributive impact of the welfare state. In Monica Budowski und Michael Nollert (eds.) Private Macht im Wohlfahrtsstaat: Akteure und Institutionen. Seismo Verlag, Zürich, pp. 188-204.

Im, K. S., Pesaran, M. H., \& Shin, Y. (2003). Testing for unit roots in heterogeneous panels. Journal of econometrics, Elsevier, 115(1), 53-74. 
Kadomtseva, S., \& Palochkina, V. (2015). The Federal Budget Appropriations Impact on Social Policy Effectiveness in the Russian Federation. Journal of Social Sciences and Humanities, 1(5), 480-487.

Kao, C. (1999). Spurious regression and residual-based tests for cointegration in panel data. Journal of econometrics, 90(1), 1-44.

Kauder, B., \& Potrafke, N. (2015). Globalization and social justice in OECD countries. Review of World Economics, 151(2), 353-376. https://doi.org/10.1007/ s10290-015-0213-1

Kim, K. (2019). Which Income Inequality Influences Which Health Indicators? Analysis of the Income Inequality Hypothesis with Market and Disposable Gini Indicators. Social Indicators Research, 146(3), 473-485. https://doi.org/10.1007/ s11205-019-02129-5

Kim, T., \& Kim, H. (2017). Which country uses public social expenditure efficiently among OECD countries? Applied Economics Letters, 24(10), 677-680. https://doi. org/10.1080/13504851.2016.1221031

Konishi, H., \& Miyazato, N. (2018). Distributive Impacts of Social Protection Systems in OECD Countries: Public-Private Mix and Hidden Welfare States (No. 1804).

Kozuharov, S., \& Petkovski, V. (2018). The impact of social transfers on inequality measured by GINI index: The example of Macedonia. UTMS Journal of Economics, 9(1), 49-61. Retrieved from http://hdl.handle.net/10419/195324

Kranzinger, S. (2019). The decomposition of income inequality in the EU-28. Empirica. https://doi.org/10.1007/s10663-019-09450-9

Levin, A., Lin, C. F., \& Chu, C. S. J. (2002). Unit root tests in panel data: asymptotic and finite-sample properties. Journal of econometrics, 108(1), 1-24.

Lin, E. S., Ali, H. E., \& Lu, Y.-L. (2015). Does Military Spending Crowd Out Social Welfare Expenditures? Evidence from a Panel of OECD Countries. Defence and Peace Economics, 26(1), 33-48. https://doi.org/10.1080/10242694.2013.848576

Maddala, G. S., \& Wu, S. (1999). A comparative study of unit root tests with panel data and a new simple test. Oxford Bulletin of Economics and statistics, 61(S1), 631-652. 
Pedroni, P. (1999). Critical values for cointegration tests in heterogeneous panels with multiple regressors. Oxford Bulletin of Economics and statistics, 61(S1), 653670 .

Pedroni, P. Fully (2001) Modified OLS for heterogeneous cointegrated panels. In Nonstationary panels, panel cointegration, and dynamic panels pp. 93-130. Emerald Group Publishing Limited.

Sánchez, Á., \& Pérez-Corral, A. L. (2018). Government Social Expenditure and Income Inequalities in the European Union. Hacienda Pública Española, 227(4), 133-156.

Seelkopf, L., \& Lierse, H. (2016). Taxation and Inequality: How Tax Competition Has Changed the Redistributive Capacity of Nation-States in the OECD BT Welfare State Transformations and Inequality in OECD Countries (M. Wulfgramm, T. Bieber, \& S. Leibfried, Eds.). https://doi.org/10.1057/978-1-137-51184-3_5

Tari, R. (2010). Ekonometri. Umuttepe Yayınlart, Kocaeli.

Tridico, P. (2017). The determinants of income inequality in OECD countries. Cambridge Journal of Economics, 42(4), 1009-1042. https://doi.org/10.1093/cje/ bex069

Ulu, M. İ. (2018). The Effect of Government Social Spending on Income Inequality in OECD: A Panel Data Analysis. Uluslararası Ekonomi Siyaset Insan ve Toplum Bilimleri Dergisi, 1(3), 184-202. https://dergipark.org.tr/en/pub/ijephss/ issue $/ 39673 / 462330$

Van Vliet, O., \& Wang, C. (2015). Social Investment and Poverty Reduction: A Comparative Analysis across Fifteen European Countries. Journal of Social Policy, 44(3), 611-638. https://doi.org/10.1017/S0047279415000070

Yilmiz, M. H., Ali, F., Mubin, M., \& Waqas, M. (2016). Income Inequality and Its Measures: Evidence from OECD and European Countries. Journal of Poverty, Investment and Development, 20(1), 9-25. SSRN: https://ssrn.com/abstract=2910695 